\title{
Prokrastinasi Kerja ditinjau dari Kepuasan Kerja dan Iklim Organisasi
}

\author{
Devy Sofyanty \\ Universitas Bina Sarana Informatika \\ e-mail: devy.dyy@bsi.ac.id
}

Abstrak - Prokrastinasi kerja adalah perilaku dimana pegawai menunda pekerjaan mereka dengan sengaja, baik untuk memulai pekerjaan, mengerjakan atau menyelesaikan pekerjaan yang telah menjadi tanggung jawabnya meskipun pegawai mengetahui lebih banyak resiko negative yang diakibatkan dari perilaku tersebut. Ironisnya perilaku tersebut cenderung berulang dan individu tidak merasa jera dengan akibat yang ditimbulkannya sehingga dapat berkembang menjadi sebuah kebiasaan. Mengkaji perilaku prokrastinasi kerja pada suatu perusahaan atau instansi menjadi penting untuk meminimaliasi atau bahkan meniadakan factor-faktor pencetus prokrastinasi kerja. Penelitian ini bertujuan untuk menguji secara empiris pengaruh kepuasan kerja dan iklim organisasi secara parsial maupun simultan terhadap prokrastinasi kerja. Penelitian ini dilakukan di Kementrian Komunikasi dan Informatika Republik Indonesia. Metode pengumpulan data menggunakan angket dan wawancara. Analisis data menggunakan regresi linier berganda. Berdasarkan hasil penelitian, maka didapatkan temuan sebagai berikut: (1) secara bersama-sama atau simultan kepuasan kerja dan iklim organisasi berpengaruh terhadap prokrastinasi kerja, (2) secara parsial kepuasan kerja berpengaruh negative dan signifikan terhadap prokrastinasi kerja, (3) secara parsial iklim organisasi berpengaruh negative dan signifikan terhadap prokrastinasi kerja.

\section{Kata Kunci: Prokrastinasi Kerja, Kepuasan Kerja, Iklim Organisasi}

\begin{abstract}
Work procrastination is a behavior where employees postpone their work intentionally, either to start work, do or complete work that has become their responsibility even though employees know more negative risks resulting from such behavior. Ironically these behaviors tend to be repetitive and individuals do not feel deterrent with the consequences they cause so that they can develop into a habit. Studying work procrastination behavior in a company or agency is important to minimize or even eliminate the factors that trigger work procrastination. This study aims to empirically examine the effect of job satisfaction and organizational climate partially and simultaneously on work procrastination. This research was conducted at the Ministry of Communication and Information of the Republic of Indonesia. Methods of data collection using questionnaires and interviews. Data analysis uses multiple linear regression. Based on the results of the study, the following findings were found: (1) simultaneously or simultaneously job satisfaction and organizational climate affect work procrastination, (2) job satisfaction partially has a negative and significant effect on work procrastination, (3) partially climate The organization has a negative and significant effect on work procrastination.
\end{abstract}

\section{Keywords: Work Procrastination, Job Satisfaction, Organizational Climate}

\section{PENDAHULUAN}

Sumber daya manusia merupakan asset penting sekaligus bernilai strategis untuk menunjang perusahaan dalam merealisasikan visi dan misi serta tujuan perusahaan. Jika dibandingkan sumber daya yang lain, manusia memiliki keunikan tersendiri bahkan jika dibandingkan dengan manusia yang lain. Hal ini dikarenakan manusia dianugerahkan Tuhan Yang Maha Esa berupa akal, cipta, rasa dan karsa sebagai media untuk mengembangkan kompetensi diri. Uniknya lagi manusia dibekali dengan seperangkat kepribadian, bakat, kecerdasan, motivasi, sifat yang unik dan berbeda-beda antara satu individu dengan individu yang lain sehingga perlu dikenali, dikembangkan, di daya gunakan bahkan harus selalu di up grade untuk mendukung penyesuaian individu terhadap kehidupan dan lingkungan sebagai wujud eksistensi manusia, tidak terkecuali dalam aspek pekerjaan. Untuk itulah perusahaan perlu melakukan deteksi dini atau screening terhadap komponen tersebut dalam rangka 
mendapatkan sumber daya manusia yang tidak hanya kompeten dalam bidangnya tapi juga mampu beradaptasi dengan cepat dan tepat, tidak hanya di dalam lingkungan perusahaan tapi juga terhadap lingkungan eksternal perusahaan. Lingkungan eksternal perusahaan seperti dan kompetisi antar perusahaan baik ditingkat lokal, nasional maupun internasional yang mengindikasikan semakin gesitnya persaingan bisnis menuntut perusahaan untuk memiliki sumber daya yang benar-benar unggul untuk memenangkan persaingan tersebut.

Istilah The Right Man In The Right Place, sekiranya tepat untuk menggambarkan kondisi tersebut, untuk itulah perusahaan sedemikian selektif dalam memilih calon karyawan. Serangkaian metode maupun proses dilakukan, mulai rekrutmen dan seleksi. Perusahaan menyeleksi mulai dari surat lamaran pekerjaan (kualifikasi, pendidikan maupun pengalaman calon karyawan), hasil tes psikologi dan wawancara. Tidak hanya sampai disitu proses pelatihan, pengembangan serta promosi jabatan perlu dilakukan secara berkesinambungan disesuaikan dengan kebutuhan perusahaan, tuntutan pekerjaan dan perkembangan zaman. Sedangkan dari sisi pegawai hal tersebut bertujuan tidak hanya memotivasi karyawan untuk selalu belajar dan bekerja lebih baik tapi juga mendayagunakan seluruh potensi baik sifatnya hard skill maupun soft skill.

Ketika seseorang mampu merealisasikan dan mendayagunakan seluruh potensi, kemampuan serta keahliannya dalam kehidupan sehari-hari, maka tercapai apa yang di sebut dengan aktualisasi diri. Pengaktualisasian diri ini akan menimbulkan suatu kondisi psikologis dimana individu mengalami kepuasan batin yang juga akan berpengaruh terhadap kesehatan mental individu. Karyawan yang mampu atau telah mengaktualisasikan diri dari sisi kesehatan mental jauh lebih baik dibandingkan mereka yang tidak dapat merealisasikan potensinya. Mereka merasakan kepuasan batin atau bahkan mengalami peak experience sebagai imbas dari peran mereka dalam menyelesaikan pekerjaan dengan memberdayakan kompetensi yang ada. Dengan kesehatan mental yang baik dapat mengindikasikan kepuasan kerja yang baik pula sehingga berdampak pada kinerja karyawan yang bersangkutan.

Kepuasan kerja mengacu pada sikap umum seorang individu terhadap pekerjaannya. Individu dengan tingkat kepuasan kerja yang tinggi memiliki sikap positif terhadap pekerjaan. Sebaliknya, individu yang tidak puas dengan pekerjaannya mempunyai sikap negative terhadap pekerjaan. (Ulum, 2016). Pendapat serupa dikemukakan oleh (Fattah, 2017), yang mendefinisikan kepuasan kerja sebagai sebuah gambaran perasaan senang dan tidak senang seorang karyawan terhadap pekerjaan yang dilakukan, kepuasan kerja merupakan respons emosional pegawai terhadap situasi kerja yang ditentukan oleh pencapaian hasil, memenuhi atau melampaui harapan. Sedangkan menurut Locke dalam (Noermijati, 2013), kepuasan kerja sebagai keadaan emosi yang menyenangkan atau positif yang dihasilkan dari penilaian atas pekerjaan atau pengalaman kerja seseorang. Kepuasan kerja merupakan hasil dari persepsi karyawan tentang sejauh mana pekerjaan mereka dapat memberikan keadaan emosi seperti itu. Ada tiga dimensi penting dari kepuasan kerja, yaitu: 1) Kepuasan kerja adalah respon emosional terhadap suatu situasi kerja, 2) Kepuasan kerja seringkali ditentukan oleh sebaik apa hasil pekerjaan (outcome) memenuhi harapan, 3) kepuasan kerja menggambarkan beberapa sikap yang berhubungan. Locke juga menyatakan bahwa kepuasan kerja dan ketidakpuasan kerja adalah fungsi dari hubungan yang dirasakan antara apa yang orang inginkan dari pekerjaan dan apa yang dia harapkan benar-benar tersedia.

Kepuasan kerja merupakan suatu kondisi psikologis individu yang secara subjektif menggambarkan tentang rasa puas atau tidak terhadap kompensasi, lingkungan kerja, jenjang karir diberikan oleh perusahaan terhadap karyawan selama bekerja di perusahaan. Semakin besar kesenjangan yang ada maka kepuasan kerja semakin kecil, demikian pula sebaliknya. Banyak hal yang menyebabkan ketidakpuasan kerja baik karena factor gaji, kondisi lingkungan kerja, factor pimpinan atau rekan kerja, karir yang stuck, pekerjaan yang tidak memberikan tantangan, kebosanan, dll. Ketidakpuasan kerja juga dapat dilihat dari sikap karyawan misalkan dari disiplin kerja, tingkat absensi, kualitas pekerjaan yang dihasilkan maupun perilaku kerja karyawan sehari-hari dikantor. Ketidakpuasan kerja dapat membuat karyawan bekerja malas-malasan, memilih untuk meninggalkan pekerjaan (resign), atau justru akan timbul kebiasaan buruk seperti prokrastinasi bahkan fraud.

Perilaku pegawai dalam bekerja maupun berinteraksi dengan pegawai lainnya ditentukan oleh bagaimana pegawai tersebut mempersepsikan diri dan lingkungan kerjanya sehingga menghasilkan pemahaman serta penginternalisasian norma perilaku yang diwujudkan dalam kecenderungan berperilaku sehingga apa yang dilakukan oleh pegawai tersebut merupakan proyeksi dari lingkungan sekitarnya. Hal inilah yang lazim dikenal dengan istilah iklim organisasi

Iklim organisasi merupakan suatu konsep yang menggambarkan sikap subjektif atau kualitas lingkungan yang dapat menjadi dasar untuk menafsirkan dan memahami keadaan sekitar lingkungan organisasi Sedangkan menurut (Wirawan, 2008), iklim organisasi adalah persepsi anggota organisasi (baik secara individual maupun berhubungan dengan organisasi, misalnya stakeholder, konsumen, konsultan dan kontraktor) mengenai berbagai hal yang ada atau terjadi di lingkungan internal organisasi secara rutin, dimana 
hal tersebut dapat mempengaruhi sikap dan perilaku organisasi serta kinerja anggota organisasi, yang kemudian menentukan kinerja organisasi

Iklim organisasi merupakan persepsi yang ada dalam anggota organisasi dan perasaan anggota organisasi mengenai elemen-elemen fundamental organisasi yang merefleksikan consensus sebagai kesepakatan antara anggota organisasi terkait elemen-elemen kunci organisasi yang terdiri atas system, praktik dan gaya kepemimpinan. (Kusumaputri, 2018)

Pendapat serupa dikemukakan oleh Davis dan Newstrom dalam (Zamzam, 2019) memandang iklim organisasi sebagai kepribadian sebuah organisasi yang membedakan dengan organisasi lainnya yang mengarah pada persepsi masingmasing anggota dalam memandang organisasi. Menurut Sagala dalam (Abas, 2017) iklim organisasi tidak dapat dilihat tetapi dapat dirasakan dan dapat memengaruhi perilaku dalam organisasi. Iklim organisasi dapat menyenangkan dapat pula tidak menyenangkan, oleh karena itu iklim organisasi dibangun melalui kegiatan dan mempunyai akibat atau dampak bagi organisasi.

Menurut Owens dalam (Soetopo, 2012) mengemukakan bahwa iklim organisasi merupakan persepsi para anggota individu terhadap berbagai macam aspek lingkungan yang ada dalam organisasi. Menurut (Usman, 2010) iklim organisasi dapat bersifat tampak atau fisik seperti: ruang kerja yang menyenagkan, penerangan yang memadai, sarana dan prasarana yang memadai, dan sebagainya. Iklim organisasi dapat pula bersifat tidak tampak mata atau emosional, seperti: rasa aman dalam bekerja, jaminan sosial yang memadai, dll. Schneider dan Snyder dalam (Kusumaputri, 2018) mendefinisikan iklim organisasi sebagai ringkasan atau persepsi global yang dimiliki oleh anggota mengenai organisasinya. Individu memahami organisasi dalam berbagai cara, tergantung pada situasi khusus mereka dan informasi yang tersedia, maka dari itu iklim organisasi dapat digambarkan sebagai personalistik, yaitu apa yang penting bagi individu adalah cara mereka memahami organisasi dan bukan bagaimana yang lain menggambarkannya.

Setiap organisasi akan memiliki iklim organisasi yang berbeda, keanekaragaman pekerjaan yang dirancang di dalam organisasi, atau sifat individu yang ada akan mendeskripsikan perbedaan tersebut. Menurut Sagala dalam (Abas, 2017) terdapat dua ekstrimitas iklim organisasi, yaitu iklim terbuka dan tertutup. Iklim terbuka memiliki derajat kepercayaan dan semangat yang tinggi dan rendahnya perlawanan. Sedangkan iklim tertutup memiliki derajat kepercayaan dan semangat yang rendah dengan tingginya perlawanan. Pada iklim terbuka para anggota memiliki kebebasan untuk berkreativitas dan melakukan inovasi, sehingga para anggota berlomba-lomba untuk menunjukkan prestasi kerja yang terbaik. Pada iklim tertutup pemimpin dan anggota ruang geraknya sempit, kaku, menekankan pada hal-hal yang bersifat rutinitas, sehingga anggota organisasi menjadi statis, frustasi dan apatis

Demikian halnya dengan alur terjadinya prokrastinasi di dalam sebuah organisasi atau perusahaan. Seorang pegawai yang mempersepsikan bahwa pegawai yang lain melakukan perilaku serupa (prokrastinasi) maka pegawai merasa tidak masalah melakukan hal serupa karena mempersepsikan bahwa rekan kerjanya yang lain melakukan hal yang sama bahkan lebih parah dari yang bersangkutan. Pegawai merasa mendapat persetujuan untuk memperkuat dan membenarkan persepsinya bahwa perilakunya juga lazim dilakukan oleh karyawan lain atau bahkan atasannya mempersilahkan perilaku tersebut.

Prokrastinasi adalah perilaku dimana pegawai menunda pekerjaan mereka dengan sengaja, baik untuk memulai pekerjaan, mengerjakan atau menyelesaikan pekerjaan yang telah menjadi tanggung jawabnya. Pegawai cenderung melakukan kegiatan atau aktivitas lain yang dirasakan lebih menyenangkan baginya, entah bermain game di computer atau di smartphone, berselancar di dunia maya, berbincang-bincang dengan rekan kerja, dll. Hal ini dipertegas dengan pendapat yang dikemukakan oleh (Hidayah, 2014) yang menjelaskan prokrastinasi adalah kegagalan untuk melakukan apa yang seharusnya dilakukan untuk mencapai tujuan. Orang yang menunda menyelesaikan tugas seharusnya diselesaikan, maka ia lebih suka menghabiskan waktu untuk ngobrol bersama teman atau menonton televisi.

Definisi prokrastinasi menurut (Imaduddin, 2018), adalah menangguhkan suatu pekerjaan atau tindakan karena alasan tidak menyenangkan, atau bahkan tanpa alasan yang jelas. Sebagian orang memiliki alasan untuk menunda suatu pekerjaan karena banyaknya pekerjaan yang harus diselesaikan, padahal sejatinya tidak demikian. Ketidakmampuan menetapkan prioritas, rendahnya komitmen dan konsistensi diri akan berujuang pada keterpurukan. Bagi para pencuri waktu yang sudah akut, akan muncul di dalam dirinya ketakutan yang mendalam sehingga bahkan tidak bisa berhadapan dengan situasi tersebut.

Silver dalam (Ghufron, 2011) menyatakan bahwa seseorang yang melakukan prokrastinasi tidak bermaksud untuk menghindar atau tidak mau tahu dengan tugasnya. Akan tetapi mereka menundanunda untuk mengerjakannya sehingga menyita waktu yang di butuhkan untuk menyelesaikan tugas. Penundaan tersebut menyebabkan dia gagal menyelesaikan tugas tepat waktu. Ironisnya lagi sekalipun mereka mengetahui resiko akibat penundaan tersebut terhadap dirinya sendiri, pekerjaan maupun perusahaan, namun sang procrastinator tidak jera dan cenderung akan 
mengulangi perbuatan serupa di masa yang akan datang. Akibatnya prokrastinasi berkembang menjadi sebuah kebiasaan buruk dan karyawan yang bersangkutan akan terjebak dalam lingkaran setan

Lebih lanjut menurut (Ghufron, 2011) mengungkapkan bahwa factor-faktor yang mempengaruhi prokrastinasi dapat dikategorikan mnejadi dua macam, yaitu: 1) prokrastinasi dapat dipengaruhi oleh factor internal, yaitu kondisi fisik individu dan kondisi psikologis individu; serta factor eksternal yaitu gaya pengasuhan orang tua dan kondisi lingkungan yang rendah pengawasan

Prokrastinasi dapat mengganggu kelancaran proses kerja internal institusi yang bersangkutan serta semakin memperburuk citra instansi. Sedangkan dari sisi sang prokrastinator dapat berdampak buruk bukan hanya dari sisi kinerja pegawai saja tapi kondisi psikologis pun ikut terganggu. Penundaan dapat mengakibatkan menumpuknya pekerjaan, menambah beban kerja, stress kerja pun meningkat sejalan dengan deadline yang telah ditetapkan. Seorang prokrastinator terpaksa harus menambah jam kerja, lembur atau menyelesaikannya di rumah. Kurang istirahat dapat menyebabkan otak sulit untuk berkonsentrasi dan menimbulkan efek psikologis seperti mudah marah, frustasi atau bahkan depresi. Kualitas pekerjaan yang dihasilkan cenderung tidak maksimal, jika terus menerus dibiarkan akan menjadi kebiasaan kronis dan dapat mengganggu kinerja organisasi

Prokrastinasi kerja di beberapa instansi pemerintahan sering menjadi sorotan public sehingga perlu segera ditindaklanjuti. Masih banyak kita lihat atau bahkan kita sendiri pernah menjadi korban penelantaran dalam pengurusan dokumen kependudukan, harus melalui se rangkaian prosedur yang berbelit-belit, lambat dan sarat unsur korupsi. Tidak hanya itu petugas dinilai tidak ramah, lambat dalam merespon keluhan masyarakat, santai dalam bekerja. Bukan rahasia umum lagi jika menginginkan dokumen cepat selesai harus memberikan uang pelicin atau uang rokok kepada petugas. Sayangnya masyarakat memakluminya dan enggan untuk melaporkannya sehingga berkembang menjadi budaya korupsi. Permasalahan lain adalah ditengah banyaknya antrian masyarakat yang menunggu pelayanan public sering ditemukan petugas yang justru malah sibuk bermain dengan hand phone nya, bersenda gurau, ngobrol dengan petugas lain yang tidak ada hubungannya dengan pekerjaan, bahkan ada petugas yang tidak sedang berada di ruangan karena datang terlambat, keluar kantor untuk merokok atau makan di jam kerja.

Berdasarkan pemikiran tersebut maka hipotesis yang diajukan dalam penelitian ini adalah sebagai berikut:
1. Ada pengaruh kepuasan kerja terhadap prokrastinasi kerja

2. Ada pengaruh iklim organisasi terhadap prokrastinasi kerja

3. Ada pengaruh kepuasan kerja dan iklim organisasi terhadap prokrastinasi kerja

\section{METODE PENELITIAN}

Jenis penelitian yang digunakan adalah kuantitatif. Populasi adalah keseluruhan subjek penelitian, adapun populasi dalam penelitian ini adalah pegawai Kementrian Komunikasi dan Informatika Republik Indonesia. Sampel adalah sebagian atau wakil dari populasi yang diteliti. Sampel dalam penelitian ini adalah pegawai pada Direktorat Jendral Informasi dan Komunikasi Publik sejumlah 120 responden. Dalam hal penentuan sampel, Arikunto dalam (Rukajat, 2018) mengatakan bahwa apabila subjek kurang dari 100, lebih baik diambil semuanya sehingga merupakan penelitian populasi. Selanjutnya bila jumlah subjeknya besar, dapat diambil antara maka pengambilan sampel $10 \%-15 \%$ atau 20\%-25\%. Teknik sampling yang digunakan adalah purposive sampling. Periode data yang digunakan dalam penelitian ini adalah bulan September 2019

Instrumen yang dipergunakan dalam penelitian ini melalui kuesioner atau angket. Alat ukur yang digunakan dalam penelitian ini terdiri dari 3 skala, yaitu skala prokrastinasi kerja yang berjumlah 12 item, skala kepuasan kerja yang berjumlah 15 item dan skala iklim organisasi yang berjumlah 15 item.

Perilaku prokrastinasi kerja diukur dengan menggunakan skala prokrastinasi kerja yang disusun berdasarkan indicator yang dikemukakan oleh Ferrari dalam (Ghufron, 2011), yaitu : (1) penundaan untuk memulai dan menyelesaikan tugas, (2) keterlambatan dalam mengerjakan tugas akibat dari mengerjakan hal-hal lain yang tidak terlalu penting, (3) kesenjangan waktu antara rencana dan kinerja actual, (4) melakukan aktivitas lain yang lebih menyenangkan. Semakin tinggi skor yang diperoleh dalam skala prokrastinasi kerja maka semakin tinggi prokrastinasi kerja yang dilakukan oleh pegawai, demikian pula sebaliknya semakin rendah skor yang diperoleh dalam skala prokrastinasi kerja maka semakin rendah prokrastinasi yang dilakukan oleh karyawan

Variabel Kepuasan kerja diukur dengan menggunakan skala kepuasan kerja yang disusun berdasarkan aspek-aspek kepuasan kerja yang dikemukakan oleh (Fattah, 2017), yaitu : (1) pekerjaan itu sendiri ; (2) kompensasi ; (3) kesempatan promosi; (4) pengawasan; (5) rekan kerja. Semakin tinggi skor yang diperoleh dalam skala kepuasan kerja maka semakin tinggi kepuasan kerja yang dirasakan oleh pegawai. Demikian pula sebaliknya, semakin rendah skor yang diperoleh dalam skala kepuasan kerja maka semakin rendah kepuasan kerja yang dirasakan oleh pegawai yang bersangkutan. 
Sementara itu variable Iklim organisasi diukur dengan menggunakan skala iklim organisasi yang disusun berdasarkan dimensi iklim organisasi yang diadopsi dari Litwin dan Stringers dalam (Muhammad, 2014), yaitu: (1) rasa tanggung jawab, (2) standar atau harapan tentang kualitas pekerjaan, (3) ganjaran atau reward, (4) rasa persaudaraan dan (5) semangat tim. Semakin tinggi skor yang diperoleh dalam skala iklim organisasi maka semakin baik iklim organisasi yang dirasakan oleh pegawai. Demikian pula sebaliknya, semakin rendah skor yang diperoleh dalam skala iklim organisasi maka semakin buruk iklim organisasi yang dirasakan oleh pegawai yang bersangkutan.

\begin{tabular}{|c|c|c|c|}
\hline Variable & Dimensi & Skala & No.Item \\
\hline $\begin{array}{l}\text { Prokrastinasi } \\
\text { Kerja }\end{array}$ & $\begin{array}{ll}\text { 1. } & \text { Penundaan } \\
\text { untuk } \\
\text { memulai dan } \\
\text { menyelesaika } \\
\text { n tugas } \\
\text { 2. } \\
\text { Mengerjakan } \\
\text { Tugas yang } \\
\text { tidak penting } \\
\text { 3. } \\
\text { Melakukan } \\
\text { aktivitas yang } \\
\text { menyenangka } \\
\mathrm{n}\end{array}$ & Ordinal & $\begin{array}{l}2,5,8,11,14 \\
3,6,9,12,15\end{array}$ \\
\hline $\begin{array}{l}\text { Kepuasan } \\
\text { Kerja }\end{array}$ & $\begin{array}{l}\text { 1. Pekerjaan itu } \\
\text { sendiri } \\
\text { 2. Kompensasi } \\
\text { 3. Kesempatan } \\
\text { promosi } \\
\text { 4. Pengawasan } \\
\text { 5. Rekan kerja }\end{array}$ & Ordinal & $\begin{array}{l}1,3,5,7,9 \\
2,4,6,8,10 \\
11,13,15,17,19 \\
12,14,16,18,20 \\
21,22,23,24, \\
25\end{array}$ \\
\hline $\begin{array}{l}\text { Iklim } \\
\text { Organisasi }\end{array}$ & $\begin{array}{l}\text { 1. Tanggung } \\
\text { jawab } \\
\text { 2. Standar atau } \\
\text { harapan } \\
\text { 3. Ganjaran atau } \\
\text { reward } \\
\text { 4. Rasa } \\
\text { persaudaraan } \\
\text { 5. Semangat tim }\end{array}$ & Ordinal & $\begin{array}{l}1,3,5,7,9 \\
2,4,6,8,10 \\
11,13,15,17,19 \\
12,14,16,18,20 \\
21,22,23,24, \\
25\end{array}$ \\
\hline
\end{tabular}

Pertanyaan-pertanyaan yang disusun dalam bentuk kuesioner diberikan kepada responden dengan tujuan agar responden dalam memberikan jawaban sesuai dengan tema sentral penelitian. Selanjutnya kuesioner diberikan bobot sesuai dengan tingkat kepentingan model skala Likert. Skala Likert ini digunakan untuk mengukur sikap, pendapat dan persepsi seseorang atau sekelompok tentang kejadian atau gejala social. (Rukajat, 2018) Semua skala yang digunakan dalam penelitian ini menggunakan model skala Likert.

Skala Likert yang digunakan dalam penelitian ini memiliki 4 alternatif jawaban. Tiap skala memiliki 4 alternatif jawaban yang telah disediakan, yaitu Sangat Setuju (SS), Setuju (S), Tidak Setuju (TS) dan Sangat Tidak Setuju (STS). Peneliti tidak memberikan alternatif pilihan ragu-ragu atau netral karena seringkali responden memiliki kecenderungan menjawab ke tengah, dan tidak dapat menunjukkan kecenderungan jawaban subjek ke arah setuju atau tidak setuju sehingga banyak data dan informasi penelitian yang tidak dapat diungkap oleh peneliti.

\section{PEMBAHASAN}

\section{Gambaran Umum Responden}

Berikut adalah tabel-tabel yang disusun untuk memberikan gambaran umum mengenai responden.

\section{Tabel 1. Profil Responden Berdasarkan Jenis Kelamin}

\begin{tabular}{|c|c|c|}
\hline Jenis Kelamin & Jumlah & $\%$ \\
\hline Pria & 58 & 48 \\
\hline Wanita & 62 & 52 \\
\hline Total & 120 & 100 \\
\hline
\end{tabular}

Sumber: Data yang Diolah (2019)

Tabel 2. Profil Responden Berdasarkan Tingkat Pendidikan

\begin{tabular}{|c|c|c|}
\hline $\begin{array}{c}\text { Pendidikan } \\
\text { Terakhir }\end{array}$ & Jumlah & $\%$ \\
\hline D III & 24 & 19 \\
\hline S -1 & 89 & 74 \\
\hline S - 2 & 8 & 7 \\
\hline Total & 120 & 100 \\
\hline
\end{tabular}

Sumber: Data yang Diolah (2019)

Tabel 3. Profil Responden Berdasarkan Usia

\begin{tabular}{|c|c|c|}
\hline $\begin{array}{c}\text { Usia } \\
\text { Responden }\end{array}$ & Jumlah & $\%$ \\
\hline $20-30$ & 17 & 14 \\
\hline $31-40$ & 79 & 66 \\
\hline $41-50$ & 24 & 20 \\
\hline Total & 120 & 100 \\
\hline
\end{tabular}

Sumber: Data yang Diolah (2019)

\section{Uji Validitas}

Uji validitas dilakukan dengan tujuan untuk mengetahui validitas dari item-item pada kuesioner. 
dalam penarikan kesimpulan dari data. Pengujian validitas, dapat dilakukan dengan menggunakan nilai sig. pernyataan dibandingkan dengan tingkat signifikansi. Nilai sig yang lebih kecil atau sama dengan nilai tingkat signifikansi ( $\operatorname{sig} \leq 0.05)$, maka item pada kuesioner dikatakan valid. Berikut adalah pemaparannya:

Tabel 4. Hasil Uji Validitas

\begin{tabular}{|c|c|c|}
\hline No & Variabel & Correction Item \\
\hline 1 & Kepuasan kerja & $0.443-0.768$ \\
\hline 2 & Iklim Organisasi & $0.358-0.863$ \\
\hline 3 & Prokrastinasi Kerja & $0.415-0.894$ \\
\hline
\end{tabular}

Sumber: Data yang Diolah (2019)

Analisis validitas skala kepuasan kerja menunjukkan bahwa item yang valid mempunyai daya beda yang bergerak dari $0.443-0.768$. Dari 15 item yang digunakan dalam penelitian didapatkan semua item valid. Demikian halnya dengan skala iklim organisasi, item yang valid mempunyai daya beda yang bergerak dari $0.358-0.863$. Dari 15 item yang digunakan, semua item dinyatakan valid. Sedangkan untuk skala prokrastinasi kerja diperoleh daya beda yang bergerak dari $0.415-0.894$. Dari 12 item yang digunakan didapatkan semua item valid.

\section{Uji Reliabilitas}

Uji reliabilitas digunakan untuk menguji tingkat keterandalan instrumen penelitian. Angket yang reliabel, jika datanya benar-benar sesuai dengan kenyataan, berapa kalipun diambil, akan tetap memberikan hasil yang sama atau konsisten. (Setiawan, 2015)

\section{Tabel 5. Uji Reliabilitas}

\begin{tabular}{|c|c|c|}
\hline Variabel & Cronbach's Alpha & Keterangan \\
\hline Prokrastinasi kerja & 0.892 & Reliabel \\
\hline Kepuasan kerja & 0.961 & Reliabel \\
\hline Iklim organisasi & 0.957 & Reliabel \\
\hline
\end{tabular}

Sumber: Data yang Diolah (2019)

Reliabilitas dalam penelitian ini menggunakan metode Alpha Cronbach. Kriteria suatu skala dikatakan reliabel apabila koefisien reliabilitas menunjukkan angka lebih dari 0.6 (Siregar, 2013)

Perhitungan reliabilitas terhadap alat ukur kepuasan kerja, iklim organisasi dan prokrastinasi kerja menghasilkan koefisien reliabilitas lebih dari
0.6 sehingga dapat disimpulkan bahwa ketiga variabel tersebut reliabel sebagai alat ukur.

\section{Uji Asumsi Klasik}

a. Uji Normalitas

Pengujian normalitas bertujuan untuk menguji apakah dalam model regresi, variabel bebas dan variabel terikat, keduanya memiliki distribusi normal atau tidak. Model regresi yang baik adalah data yang berdistribusi normal atau mendekati normal. (Sujarweni, 2014)

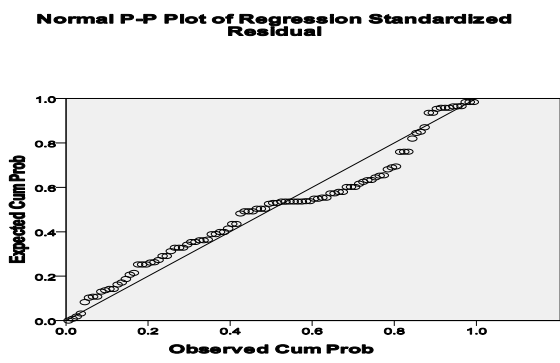

Gambar 1.Uji Normalitas

Hasil uji normalitas yang diperoleh dari penggunaan grafik normal probability plot dalam penelitian ini menunjukkan bahwa titik-titik menyebar disekitar garis diagonal dan penyebarannya pun mengikuti garis diagonal. Sehingga dapat ditarik kesimpulan bahwa penyebaran data dalam penelitian ini sudah terdistribusi dengan normal atau sudah memenuhi asumsi normalitas.

Tabel 6. Uji Kolmogorov - Smirnov

\begin{tabular}{|c|c|c|}
\hline & & $\begin{array}{l}\text { Unstandardized } \\
\text { Residual }\end{array}$ \\
\hline \multicolumn{2}{|l|}{$\mathrm{N}$} & 120 \\
\hline \multirow{2}{*}{$\begin{array}{l}\text { Normal } \\
\text { Parameters }{ }^{\mathrm{a}, \mathrm{b}}\end{array}$} & Mean & .0000000 \\
\hline & Std. Deviation & 4.10435373 \\
\hline \multirow{3}{*}{$\begin{array}{l}\text { Most Extreme } \\
\text { Differences }\end{array}$} & Absolute & .094 \\
\hline & Positive & .094 \\
\hline & Negative & -.087 \\
\hline \multicolumn{2}{|c|}{ Kolmogorov-Smirnov Z } & .940 \\
\hline \multicolumn{2}{|c|}{ Asymp. Sig. (2-tailed) } & .339 \\
\hline \multicolumn{3}{|c|}{ Sumber: Data yang Diolah (2019) } \\
\hline
\end{tabular}

Sementara itu pengujian normalitas dengan menggunakan Kolmogorov-Smirnov test, diperoleh nilai Asymp sebesar 0.339 sehingga dapat ditarik kesimpulan bahwa data terdistibusi normal dan sampel penelitian mewakili populasi.

\section{b. Uji Multikolinearitas}


Multikolinearitas dapat terjadi jika adanya hubungan linier yang sempurna atau hampir sempurna diantara beberapa atau seluruh variabel independen dalam model regresi. Uji multikolinearitas memiliki tujuan untuk menguji keberadaan korelasi antar variabel bebas dalam model regresi. Model regresi yang baik seharusnya tidak terjadi korelasi diantara variabel bebas. Untuk menguji keberadaan multikolinearitas dapat dilakukan dengan cara menganalisis korelasi antar variabel dengan menggunakan perhitungan tollerance dan Variance Inflation Factor (VIF). (Sujarweni, 2014)

Tabel 7. Uji Multikolinearitas

\begin{tabular}{ccc}
\hline Model & $\begin{array}{c}\text { Collinearity } \\
\text { Statistics }\end{array}$ \\
& Tolerance & VIF \\
\hline $\begin{array}{c}\text { Constant } \\
\text { Kepemimpinan }\end{array}$ & \\
Transformasional & .920 & 1.087 \\
Iklim Organisasi & .920 & 1.089 \\
& & \\
\hline Sumber: Data yang Diolah (2019)
\end{tabular}

Berdasarkan hasil uji multikolinearitas menunjukkan nilai tolerance untuk semua variabel independen, yaitu kepuasan kerja dan iklim organisasi $>0.10$. Sementara nilai VIF yang didapat $<$ 10. Dengan demikian dapat disimpulkan bahwa tidak terjadi korelasi diantara variabel independen.

\section{c. Uji Heteroskedastisitas}

Uji heteroskedastisitas bertujuan untuk menguji apakah dalam model regresi terjadi ketidaksamaan variance residual satu pengamatan ke pengamatan yang lain. (Ghozali, 2011)

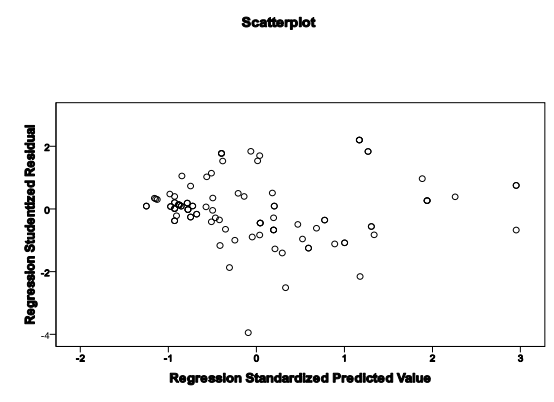

Gambar 2. Uji Heteroskedastisitas

Berdasarkan gambar grafik scatterplot tersebut menunjukkan bahwa titik-titik data menyebar secara acak dan tidak membentuk suatu pola yang jelas baik diatas maupun dibawah sumbu Y. Hal ini mengindikasikan bahwa variance tetap dari residual satu ke pengamat ke pengamat yang lain.

\section{Tabel 8. Uji Glejser}

\begin{tabular}{|c|c|c|c|c|c|c|}
\hline \multirow{2}{*}{\multicolumn{2}{|c|}{ Model }} & \multicolumn{2}{|c|}{$\begin{array}{c}\text { Unstandardized } \\
\text { Coefficients }\end{array}$} & \multirow{2}{*}{\begin{tabular}{|c|}
$\begin{array}{c}\text { Standardiz } \\
\text { ed } \\
\text { Coefficient } \\
\mathrm{s}\end{array}$ \\
\\
Beta \\
\end{tabular}} & \multirow[b]{2}{*}{$\mathrm{t}$} & \multirow[b]{2}{*}{ Sig. } \\
\hline & & B & $\begin{array}{l}\text { Std. } \\
\text { Error }\end{array}$ & & & \\
\hline \multirow[t]{3}{*}{1} & (Constant) & 1.746 & 3.117 & & .560 & .577 \\
\hline & kepuasankerja & .013 & .030 & .047 & .422 & .674 \\
\hline & iklimorganisasi & .015 & .037 & .043 & .394 & .695 \\
\hline
\end{tabular}

Sumber: Data yang Diolah (2019)

Sementara itu pengujian heteroskedastisitas dengan menggunakan Uji Glejser diperoleh nilai signifikan lebih besar dari 0.05 dimana signifikansi variabel kepuasan kerja bernilai 0.422 dan 0.394 untuk variabel iklim organisasi. Sehingga dapat disimpulkan tidak terjadi gejala heteroskedastisitas dalam penelitian ini.

\section{Uji Hipotesis \\ a. Koefisien Determinasi $\left(\mathbf{R}^{2}\right)$}

$\mathrm{R}$ menunjukkan korelasi antara dua atau lebih variabel independen terhadap variabel dependen. Nilai $\mathrm{R}$ berkisar antara $0-1$. Jika nilainya mendekati 1, maka hubungan semakin erat. Sebaliknya, jika mendekati 0, maka hubungan semakin lemah. (Priyatno, 2009)

Tabel 9. Uji R

\begin{tabular}{|c|c|c|c|c|}
\hline Model & $\mathrm{R}$ & R Square & $\begin{array}{c}\text { Adjusted R } \\
\text { Square }\end{array}$ & $\begin{array}{c}\text { Std. Error of the } \\
\text { Estimate }\end{array}$ \\
\hline 1 & $.833^{\mathrm{a}}$ & .694 & .689 & 5.271 \\
\hline
\end{tabular}

Sumber: Data yang Diolah (2019)

Berdasarkan analisis terhadap pengaruh kepuasan kerja dan iklim organisasi terhadap kinerja karyawan didapat $\mathrm{R}$ sebesar 0.833 Jadi dapat disimpulkan bahwa terjadi hubungan yang erat antara variabel kepuasan kerja dan iklim organisasi terhadap prokrastinasi kerja. Sedangkan nilai koefisien determinasi yang didapat adalah 69,4\%, artinya sumbangan pengaruh kepuasan kerja dan iklim organisasi sebesar $69,4 \%$ sedangkan sisanya sebesar 30,6\% dipengaruhi oleh variabel lain yang tidak dimasukkan dalam penelitian ini.

\section{b. Uji Hipotesis Simultan (Uji F)}

Pengujian hipotesis secara simultan (Uji F) digunakan untuk mengetahui besarnya pengaruh yang bermakna variabel independen secara bersamasama (simultan) terhadap variabel dependen. 
Tabel 10. Uji F

\begin{tabular}{|c|c|c|c|c|}
\hline Model & $\begin{array}{l}\text { Sum of } \\
\text { Squares }\end{array}$ & $\begin{array}{l}\text { Mean } \\
\text { Square }\end{array}$ & $\mathrm{F}$ & Sig. \\
\hline $1 \begin{array}{c}\text { Regres } \\
\text { sion }\end{array}$ & 7989.343 & 3994.671 & 143.752 & $.000^{\mathrm{a}}$ \\
\hline $\begin{array}{c}\text { Residu } \\
\text { al }\end{array}$ & 3529.149 & 27.789 & & \\
\hline Total & 11518.492 & & & \\
\hline
\end{tabular}

Sumber: Data yang Diolah (2019)

Berdasarkan tabel diatas, diperoleh $\mathrm{F}$ hitung sebesar 143.752 dengan nilai signifikansi $0.000<$ 0.05 sehingga dapat ditarik kesimpulan kepuasan kerja dan iklim organisasi secara bersama-sama mempengaruhi prokrastinasi kerja.

\section{Tabel 11. Uji t}

\begin{tabular}{|c|c|c|c|c|c|}
\hline \multirow[t]{2}{*}{ Model } & \multicolumn{2}{|c|}{$\begin{array}{c}\text { Unstandardized } \\
\text { Coefficients }\end{array}$} & \multirow{2}{*}{$\begin{array}{c}\text { Standar } \\
\text { dized } \\
\text { Coeffici } \\
\text { ents } \\
\text { Beta }\end{array}$} & \multirow[t]{2}{*}{$\mathbf{t}$} & \multirow[t]{2}{*}{ Sig } \\
\hline & B & $\begin{array}{l}\text { Std. } \\
\text { Error }\end{array}$ & & & \\
\hline Constant & 139.47 & 5.404 & & 25.807 & .000 \\
\hline Kepuasan & 2 & .055 & -.825 & - & .000 \\
\hline Kerja & -.886 & .069 & -.494 & 16.107 & .000 \\
\hline Iklim & -.661 & & & -.9 .638 & \\
\hline Organisasi & & & & & \\
\hline
\end{tabular}

Sumber: Data yang Diolah (2019)

\section{c. Uji Hipotesis Parsial (Uji t)}

Tujuan dari Uji $t$ adalah untuk mengetahui apakah secara parsial variabel independen berpengaruh signifikan terhadap variabel dependen. Uji ini dilakukan untuk memeriksa lebih lanjut variabel independen manakah yang berpengaruh signifikan terhadap kinerja karyawan.

1) Hipotesis 1 : Pengaruh kepuasan kerja terhadap prokrastinasi kerja.

Hasil uji hipotesis 1 diperoleh nilai $t$ hitung variabel kepuasan kerja sebesar -0.886 dengan nilai signifikansi $0.000<0.05$, maka dapat ditarik kesimpulan bahwa kepuasan kerja berpengaruh negative dan signifikan terhadap prokrastinasi kerja. Dengan demikian $\mathrm{H}_{0}$ ditolak, dan hipotesis alternatif $\mathrm{H}_{1}$ " kepuasan kerja memiliki pengaruh negatif dan signifikan terhadap prokrastinasi kerja" Diterima.

2) Hipotesis 2 : Pengaruh iklim organisasi terhadap prokrastinasi kerja

Hasil uji hipotesis 2 diperoleh nilai t hitung variabel iklim organisasi sebesar -0.661 dengan nilai signifikansi $0.000<0.05$, maka dapat ditarik kesimpulan bahwa iklim organisasi berpengaruh negative dan signifikan terhadap prokrastinasi kerja. Dengan demikian $\mathrm{H}_{0}$ ditolak, dan hipotesis alternatif $\mathrm{H}_{2}$ " iklim organisasi memiliki pengaruh negative dan signifikan terhadap kinerja karyawan" Diterima.

\section{Analisis Regresi Linier Berganda}

Tujuan dari analisis regresi berganda adalah untuk menguji dua atau lebih variabel independen terhadap variabel dependen. Dalam hal ini untuk menganalisis apakah ada perilaku prokrastinasi kerja yang dilakukan oleh karyawan disebabkan karena minimnya kepuasan kerja yang dirasakan atau karena iklim organisasi yang mendukung terjadinya perilaku prokrastinasi kerja. Adapun persamaan regresi linier berganda untuk variabel kepuasan kerja dan iklim organisasi terhadap perilaku prokrastinasi kerja adalah sebagai berikut :

$$
Y^{\wedge}=139.472-0.886 X_{1}-0.661 X_{2}
$$

Konstannta $(\alpha)$ sebesar 139.472 bernilai positif, yang berarti apabila kepuasan kerja dan iklim organisasi dianggap konstan atau tetap, maka ratarata nilai prokrastinasi kerja pegawai sebesar 139.472 Hal ini menunjukkan bahwa prokrastinasi kerja tergolong tinggi karena nilai $\alpha$ melebihi 1 , untuk itu semua variabel bebas yang mempengaruhi prokrastinasi kerja dalam penelitian ini sebaiknya di minimalisasi. Organisasi diharapkan dapat lebih tegas dalam membuat, mengimplementasikan bahkan mengevaluasi sebuah kebijakan yang disertai pula dengan pengawasan. Perlunya juga ditumbuhkan kesadaran akan tanggung jawab dari dalam diri pegawai terhadap organisasi maupun pegawai, hal ini dapat ditumbuhkan melalui serangkaian kegiatan seperti: seminar, workshop, gathering. Perlunya bagian biro kepegawaian memberikan layanan konseling maupun terapi untuk mengubah sikap dan perilaku karyawan ke arah positif untuk memperbaiki disiplin karyawan.

Koefisien regresi kepuasan kerja $\left(b_{1}\right)$ bernilai 0.886 menunjukkan hubungan negative (berlawanan arah) antara kepuasan kerja dengan prokrastinasi kerja. Hasil ini menunjukkan semakin rendah kepuasan kerja maka akan diikuti dengan meningkatnya prokrastinasi kerja. Demikian pula sebaliknya jika semakin tinggi kepuasan kerja maka prokrastinasi kerja semakin rendah. Peningkatan kepuasan kerja dapat dilakukan antara lain dengan memberikan gaji atau kompensasi yang kompetitif, memberikan kesempatan secara adil kepada karyawan untuk mengembangkan potensinya dengan mengadakan pelatihan maupun pengembangan secara rutin dan perlu juga dipertimbangkan program promosi jabatan maupun pelelangan jabatan yang transparan

Koefisien regresi iklim organisasi $\left(b_{2}\right)$ yang bernilai -0.661 menunjukkan hubungan negative (berlawanan arah) antara iklim organisasi dengan prokrastinasi kerja. Hasil ini menunjukkan semakin rendah iklim organisasi akan diikuti dengan semakin tingginya prokrstinasi kerja pegawai. Demikian pula sebaliknya semakin tinggi iklim organisasi maka 
akan diikuti dengan semakin rendahnya prokrastinasi kerja pegawai. Diharapkan kepada organisasi dapat menciptakan iklim organisasi yang kondusif sehingga dapat meningkatkan motivasi kerja karyawan sehingga prokrastinasi kerja dapat diminimalisasi atau bahkan dihilangkan. Peningkatan SDM melalui iklim organisasi yang kondusif perlu dibina dan dikembangkan guna menciptakan iklim kerja yang "sehat" diantaranya dengan terciptanya suasana kerja yang harmonis, saling mendukung satu sama lain, pola interaksi dan komunikasi yang terbuka sehingga mampu menghadapi tantangan pada era revolusi industry 4.0 seperti sekarang ini. Hal lain yang dapat dilakukan adalah dengan menyesuaikan karakteristik karyawan seperti (kepribadian, sifat, kecerdasan, kompetensi, pengalaman) dengan beban kerja maupun karakteristik pekerjaan. Mutasi karyawan perlu juga dilakukan untuk memberikan suasana dan tantangan kerja baru sehingga mampu meningkatkan motivasi kerja serta terus belajar mengembangkan diri. Selain itu pimpinan, atasan atau manajer harus mampu melaksanakan tugas dan tanggung jawab kepemimpinan yang bersifat terbuka, memperhatikan kebutuhan dan menjaga hubungan kerja sama yang harmonis diantaranya dengan membuka ruang interaksi dan komunikasi yang terbuka, sehingga karyawan tidak merasa takut atau sungkan dalam memberikan keluhan, saran atau alternatif solusi pemecahan masalah.

\section{KESIMPULAN}

Berdasarkan hasil penelitian yang telah peneliti lakukan pada Direktorat Jendral Informasi dan Komunikasi Publik, Kementrian Komunikasi dan Informatika Republik Indonesia dapat disimpulkan bahwa kepuasan kerja dan iklim organisasi secara parsial maupun simultan berpengaruh negative dan signifikan terhadap prokrastinasi kerja. Untuk penelitian selanjutnya hendaknya dapat menambahkan variabel prediktor lainnya yang mempengaruhi prokrastinasi kerja, seperti: stress kerja, psychological well being, kompensasi, kontrak psikologis, etos kerja, motivasi kerja dan komitmen organisasi, sehingga dapat mengungkap banyak wacana dengan sudut pandang yang lebih luas. Pengambilan data juga dapat disempurnakan dengan tidak hanya menggunakan teknik kuesioner namun juga menggunakan teknik wawancara, observasi maupun tes psikologi. Hal tersebut dilakukan dengan maksud agar data yang diambil semakin komprehensif.

\section{REFERENSI}

Abas, E. (2017). Magnet Kepemimpinan Kepala Madrasah Terhadap Kinerja Guru . Jakarta: PT Elex Media Komputindo .

Fattah, H. (2017). Kepuasan Kerja dan Kinerja Pegawai. Yogyakarta: Elmatera.

Ghozali, I. (2011). Aplikasi Analisis Multivariate dengan Program IBM SPSS 19. Semarang: Badan Penerbit Universitas Diponegoro.

Ghufron, R. R. (2011). Teori - Teori Psikologi. Yogyakarta: Ar Ruzz Media.

Hidayah, A. A. (2014). Landasan Sosial Budaya dan Psikologis Pendidikan. Malang: Gunung Samudera.

Imaduddin, A. (2018). Memahami Arti Perubahan . Tasikmalaya : Edu Publisher .

Kusumaputri, E. S. (2018). Komitmen Pada Perubahan Organisasi dalam Perspektif Islam dan Psikologi. Yogyakarta: Deepublish.

Muhammad, A. (2014). Komunikasi Organisasi. Jakarta : Bumi Aksara.

Noermijati. (2013). Kajian Tentang Aktualisasi Teori Hezberg, Kepuasan Kerja dan Kinerja Spiritual Manajer Operasional. Malang : UB Press.

Priyatno, D. (2009). 5 Jam Belajar Olah Data dengan SPSS 17. Jakarta: Andi.

Rukajat, A. (2018). Pendekatan Penelitian Kuantitatif. Yogyakarta: Deepublish.

Sagala, S. (2009). Memahami Organisasi Pendidikan. Bandung : Alfabeta.

Setiawan, B. 2. (2015). Teknik Praktis Analisis Data Penelitian Sosial dan Bisnis dengan SPSS. . Yogyakarta: Andi.

Soetopo, H. (2012). Perilaku Organisasi: Teori dan Praktik di Bidang Pendidikan. Bandung : Remaja Rosdakarya.

Ulum, C. (2016). Perilaku Organisasi : Menuju Orientasi Pemberdayaan. Malang : UB Press.

Umiarso. (2018). Kepemimpinan transformasional Profetik Kajian Paradigmatik Onto Integralistik di Lembaga Pendidikan Islam . Jakarta: Prenada Media Grup.

Usman, H. (2010). Manajemen: Teori, Praktik, dan Riset Pendidikan . Jakarta: Bumi Aksara.

Wirawan. (2008). Budaya dan Iklim Organisasi . Jakarta: Salemba 4.

Zamzam, F. (2019). Good Governance Sekretaris $D P R D$. Yogyakarta : Deepublish . 